\title{
The Dehumanization of Women in the W.S Rendra's Blues Untuk Bonnie Antology
}

I Ketut Sudewa *

Article history:

Received April $15^{\text {th }}, 2016$

Revised May 20 ${ }^{\text {th }}, 2016$

Approved June $24^{\text {th }}, 2016$

\section{Keywords:}

Dehumanization;

Women;

Powerlessness;

Social services;

Appreciate.

\begin{abstract}
Many social problems expressed by Rendra in the poetry anthology Blues Untuk Bonnie, such as matters of love and lives of women. Rendra exposing this problem because he loved women, especially his mother. Women's life issues of his concern was the dehumanization of women. The dehumanization of women in this anthology discussed with sociological theory of literature and semiotics. The method used is qualitative research method in the form of a literature study. The results showed that Rendra discloses various forms of dehumanization experienced by the women, especially in the sexual and other social services. Dehumanization of women committed by officials or people who have a lot of money. Rendra explained that concern with proper diction so that the message conveyed easily understood by the reader. In semiotics, the meaning behind the dehumanization of women is society should be able to appreciate women as human beings. Sociologically, the dehumanization of women caused by the powerlessness of women, both economically and physically.
\end{abstract}

Copyright (C) 2016 International Journal of College and University. All rights reserved.

Article cited by | DOI |Orcid | OAI DOAJ | Thomson Reuters | Scopus |

Author correspondence:

First Author,

Indonesian Literary Studies Program, Faculty of Literature and Culture, University of Udayana

Jalan Nias No. 13 Sanglah

Email: sudewa.ketut@yahoo.co.id

\section{Introduction}

The literary work is a creative work that was created by the authors as individuals and as social beings. As an individual, he expressed the literary ability that his work has an aesthetic value and useful to the reader or the public. In the context of aesthetics, he will give a typical individual aesthetic distinguishing the work of other writers. In addition to his typical work of the aesthetic angle, his work also should be enjoyed and understood by the reader or the public. The literary work is worthless if it cannot be enjoyed by readers because it would be an abstract and dead work. Teeuw (1984: 191) stated that the literary work is an artifact or an inanimate object, it would have meaning or aesthetic object if it is interpreted by the reader through reading process. Therefore, the reader becomes an important factor as the meaning maker.

As social beings, the author must give attention to the reader as the meaning maker and social circumstances at the time of his work is created. This will create social aesthetics determine the acceptance of the reader or public to their works. Authors should not only promote individual aesthetic, but also social aesthetics so that his work can be fully received and interpreted by the reader. Both aesthetics must support each other in order to create a distinctive and qualified literary works and express social conditions of its people.

Collaboration of both aesthetic is a means to create qualified literary works, it would be meaningless if it ignores the presence of readers as a greeter literature. In this context, the presence of the reader becomes

\footnotetext{
* Indonesian Literary Studies Program, Faculty of Literature and Culture, Udayana University
} 
important, even the reader will determine the history of a literary work. Furthermore, Jauss (1974: 12-14) said that the first reader on a literary work will be enriched by a further response from the next reader. The response of each reader is not equal because of his experience and knowledge are not equal and fluctuated. Therefore, the results of the reading of every reader from time to time is also changed. The experience and knowledge that is constantly changing is called the "horizon of expectation" of the readers. According to Segers (1978: 41) horizon of expectation is determined by three things: (1) norms emanating from the texts that have been read by the reader; (2) knowledge and experience of all the text that has been read before; and (3) disputes between fiction and reality, either in the "narrow" and "broad" horizon context.

W.S Rendra is a writer who combine individuals and social aesthetics. No one doubted his individual aesthetics ability and his social sensitivity or his social aesthetics in the work. Rendra claimed that he worked based on a social reality which is called as a fact (2001: 14). Therefore, his works, especially poetry and drama widely read by people in Indonesia and in other countries. The anthology of his poems reprinted several times, even translated into many languages. This indicates that Rendra's poems interesting to readers and need to be researched. The necessity of assessing Rendra's work has been expressed by Sudewa (2012).

One of interesting of Rendra's poems anthology to be studied is Blues Untuk Bonnie (1971). This anthology has been reprinted twice, the second printing in 1976 and the third printing in 1981. There are thirteen poems in it. In this anthology, various issues in society is expressed, ranging from problem of love to the social problems of the community. From the thirteen poems, nine poems reveal about love problems or women's lives. Three of the nine poems describe the problem of dehumanization against women, namely: "Bersatulah pelacur-pelacur kota Jakarta", "Pesan Pencopet kepada Pacarnya", and "Nyanyian Angsa". For more details, shown in the following table.

\begin{tabular}{|c|l|c|}
\hline No. & \multicolumn{1}{|c|}{ Poetry Title } & Issue/Contents/Scene \\
\hline 1 & Kupanggil namamu & Love/women's lives \\
\hline 2 & Kepada MG & Love/women's lives \\
\hline 3 & Nyanyian Duniawi & Love/women's lives \\
\hline 4 & Nyanyian Suto untuk Fatima & Love/women's lives \\
\hline 5 & Nyanyian Fatima untuk Suto & Sove/women's lives \\
\hline 6 & Blues untuk Bonnie & Love/women's lives \\
\hline 7 & Rick dari Corona & Social Issues \\
\hline 8 & Kesaksian tahun 1967 & Social Issues \\
\hline 9 & Pemandagan Senjakala & Women Dehumanization \\
\hline 10 & Bersatulah pelacur-pelacur Kota Jakarta & Women Dehumanization \\
\hline 11 & Pesan Pencopet kepada Pacarnya & Women Dehumanization \\
\hline 12 & Nyanyian Angsa & Social Issues \\
\hline 13 & Khotbah & \\
\hline
\end{tabular}

The dehumanization of women issues in this anthology interesting to be studied consider that Rendra actually conveying social criticism through three such poems as a form of "vitality" of its in art (Rendra, 1999: 111; 2001: 19). Rendra criticize the dehumanization of women because he loved women, especially his mother and he had a view about his ideal female figure (Sudewa, 2012:147). Therefore, the problem discussed in this paper is how Rendra describe the dehumanization of women in this anthology and what the meaning behind the dehumanization is. It is considered that the work, especially poetry convey something indirectly. Riffatere (1978:2) said that there is an indirectness of expression in poetry. The indirectness was caused by: (a) change of meaning; (B) meaning deviations; and (c) the creation of meaning.

\section{Research Method}

The method used is a qualitative research through literary review. The poems in the Blues Untuk Bonnie anthology read deeply, identified, and classified through read and observe techniques. Then, interpreted the signs concerning the sociological aspect especially dehumanization of women who are in the anthology. In this way, the discussion of the dehumanization of women and their meaning can be thoroughly discussed.

In order to discuss this issues, the sociological literature and semiotics theory are used. The literary work, besides as an aesthetic document, as well as a document that has sociological value for a variety of social issues disclosed in the literature. This is because there is no literary works in vacant situations (Teeuw, 1980: 11). It means, every literary work always reflects the social conditions and the social environment of the authors, even as a reflection of reality (Jonah, 1986: 7). It also said that a successful literary work is a literary work that is capable reflects his era (Endraswara, 2008: 77). In this context, the literature sociological research becomes important. 
The use of sociological theory of literature in the literature research by notice the relationship between the concrete elements in literature and social culture elements at the time the literary work is created (Jonah, 1986: 36). The concrete meant is not a social reality in the society as mechanical as it is, but a concrete relationship between literatures as imaginary works with a socio-cultural overview in the relevant literature. Baldick (1990: 207) asserts that the sociology of literature is literary study that looked at the relationship between literature in the social context of the community, in which there are patterns of literature, a variety of readers, the publication model, dramatic presenting, and the authors and readers social class position. Based on the concept of literary sociology, the theory used in this research is the Diana Laurenson and Allan Swingeword theory (1972: 16-22). It is said that there are three perspectives related to sociological literature research, namely: (1) a perspective that view literature as a social document reflects the situation when the literary works was created; (2) a perspective that reflects the social situation of authors; (3) literary works model as a manifestation of social and cultural conditions or historical events. In the context of this research, the poems in the Blues Untuk Bonnie anthology is seen as a social document that reflects the social and cultural situation when the literary work was created and reflected the social situation of authors.

In order to find the meaning lies behind the dehumanization of women in the anthology Blues untuk Bonnie, the semiotic theory becomes important. Philosophically, semiotic theory starts from the understanding that everything in this world is a sign that has a specific meaning. Semiotic theory is a continuity or a reaction to the previous structuralism theory which then known as dynamic structuralism (Teeuw, 1983: 82). Therefore, a semiotic analysis is a continuity or development of the structuralism theory, both are inseparable.

Semiotics is defined as science of signs (North, 1990:3) which has a specific meaning, not only semiotically researchable literary works, but almost all other fields of science (Zaimar, 2008: 2). Through the words of the poems in the Blues untuk Bonnie anthology, it is seen as a sign that has a meaning. To understand the meaning of the signs in poetry, Riffatere theory is used (1978:4-6). It is said that to find a meaning of a sign in the poem must trough two stages readings. Firstly, the heuristics reading, the reader enter or be in a language or linguistic competence. In this stage, the reading is based on the structure or language conventions. Secondly, retroactive or hermeneutic reading. The reading at this stage based on literary conventions by interpreting or construing the meaning according to the literary conventions.

By using the literary sociology theory of Diana Laurenson and Allan Swingeword and semiotic theory of Riffatere mentioned above, the problem in this research can be answered completely. The result scientifically can be answered and enrich the literature research.

\section{Results and Analysis}

The Dehumanization is the removal of human dignity. Humans are treated as non-human, like animal. The occurrence of dehumanization of humanity cases, especially against women occur in developing countries, including Indonesia. In general, sociologically the life of people in developing countries are underdeveloped, particularly in education and the economy. Living in poverty and the lack of human resources of people in developing countries caused poverty intensified. This situation raises many social problems in society. They will do anything to fulfil their need. Criminal, corruption, exploitation of humanity cases, including dehumanization of women and children occurred. The poor are people who are weak in economics, including women and children. They willingly enforced inhuman (dehumanized) by others in order to live. For certain people, the weakness of the poor, especially women and children are exploited economically. The Beauty of a woman are also exploited by the capitalists as a means of promotion of their products. It's really dropped the dignity of women (Soekarno putri, 1996: 49). It happens in the big cities that the people are unemployed. Rendra observed such situation of people, then write it in the form of poetry. This situation shows that the sight of a literary work as a social document in which is a reflection of the situation at the time the literary work was created, such as the of Diana Laurenson and Allan Swingeword theories.

The dehumanization of women is revealed in the three Rendra's poems as in the table above concerns of the dehumanization of sexual and social services. Sexual field is a most convenient and high economic value for exploitable and can bring a huge profit within a certain period. In his poem titled "Pelacur-Pelacur Kota Jakarta ", Rendra describes the dehumanization of women as follows.

Pelacur-pelacur kota Jakarta

dari klas tinggi dan klas Rendah

telah diganyang

telah diharu-biru

Mereka kecut

keder

terhina dan tersipu-sipu 
When it is read heuristically like Riffatere's theory, appears the verses above as follows.

\author{
Pelacur-pelacur (yang ada di) kota Jakarta \\ (mulai) dari klas (yang bertarif) tinggi dan klas (yang bertarif) Rendah \\ telah diganyang (oleh penguasa atau trantib) \\ telah diharu-biru (secara sewenang-wenang) \\ Mereka (merasa) kecut \\ (dan) keder \\ (juga) terhina dan tersipu-sipu (karena malu)
}

From the heuristics reading above, it is hermeneutically means that the sociological condition of Jakarta as the capital of the country has a lot of social problems in it, such as prostitution as a poverty effect. It also happens in other major cities. Poet preach to the reader that the prostitutes in the city, both high class prostitute with high tariffs and low class prostitute with a low tariffs eradicated and being chased by law enforcement or authorities arbitrarily. The poet uses the diction "diganyang" and "diharu-biru" to nurture the idea how terrible the fate of women prostitutes with the aim to develop a sense of reader's empathy to prostitutes. As an effect of the action ruling, the prostitutes were very scared and they felt humiliated and embarrassed toward the society. The poet uses the words "kecut", "keder", "terhina" and "tersipu-sipu" to describe the psychological condition of the prostitutes when "diganyang" and "diharu-biru" by the authorities.

Based on the interpretation of the verses above, it seems that the poet intends to reveal the dehumanization of women prostitutes, the authorities act arbitrarily to prostitutes and treated inhumanely. Prostitutes are human beings who still have self-esteem, shame and fear as well as other human beings. It is the fate which makes them prostitutes. This is the picture or reflection of the social problems of the city. Poet indirectly express criticism of the authorities not to act arbitrarily to the people, even though they were prostitutes.

The dehumanization of women prostitutes more clearly expressed by Rendra in the next verse.

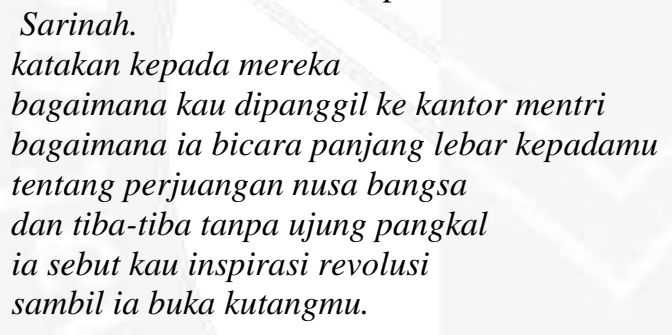

When it is read heuristically, the verses above looked as follows.

(kamu) Sarinah. (nama salah seorang pelacur)

Katakan(lah) kepada mereka (penguasa atau pejabat negara)

bagaimana (ketika) kau dipanggil (menghadap) ke kantor mentri

bagaimana ia (penguasa atau pejabat itu) (ber) bicara panjang lebar kepadamu

tentang perjuangan nusa bangsa (Indonesia)

dan tiba-tiba tanpa ujung (dan) pangkal

ia (penguasa atau pejabat) (menyebut) sebut kau inspirasi (dari) revolusi

sambil ia (penguasa atau pejabat tersebut) (mem)buka kutangmu.

From heuristically reading above, it can be interpreted as meaning through hermeneutics text. Poet asked a women prostitute named Sarinah to tell the truth to the authorities or officials, that she has imposed inhuman by individual ruler or official, namely sexual harassment. Sexual harassment by individual ruler or official when Sarinah summoned to the office of minister. Sarinah talk at length by the government officials about the struggle of Indonesia, even Sarinah regarded as inspiring revolution that actually cannot be understood by Sarinah. However, while speaking, unscrupulous rulers or the official loosen the "kutang" worn by Sarinah. The poet uses the diction "kutangmu" to strengthen the atmosphere of harassment by concerned unscrupulous ruler or officials. The word "kutang" means women's underwear to cover or buffer her breasts. This situation indicates that the poet wanted to show there has been a dehumanization of women prostitutes by powerful individuals or officials.

The case experienced by Sarinah also experienced by Dasima. Rendra revealed through the following poem.

Dan kau, Dasima. 


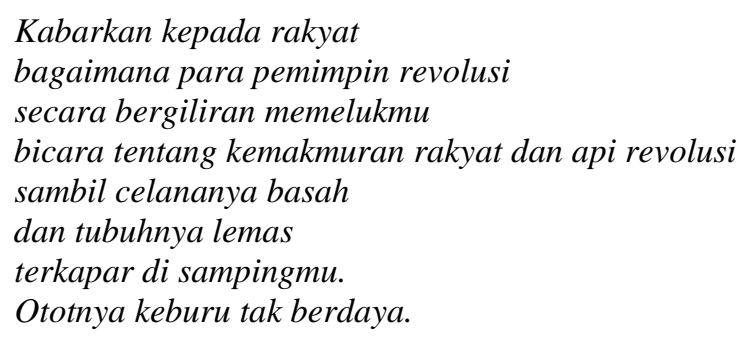

Through heuristically reading, then looks verses above as follows.

Dan kau, (juga) Dasima.

Kabarkan (juga) kepada rakyat (banyak) bagaimana para pemimpin revolusi (kita) secara bergiliran memelukmu (sambil) bicara tentang kemakmuran rakyat dan api revulusi (dahulu) sambil celananya (yang dipakainya) basah dan tubuhnya (juga) lemas terkapar (dan tertidur) di sampingmu.

Ototnya keburu tak berdaya. (karena kelelahan)

Through the hermeneutics reading, the verses can be interpreted that Dasima, female prostitutes who were also sexually harassed by the authorities or officials ("pemimpin revolusi"). The poet asked Dasima to be courage to tell the public the behavior of the authorities or officials of sexually harassing her in turns to hug her while talking about the prosperity of the people and the revolution. Then, they were limp and lying helpless in your side because of fatigue after releasing their desire through sexual harassment. The poet uses the diction "celananya basah" as a sign of sexual satisfaction. The word "lemas", "terkapar" and "tak berdaya" to describe the state authorities or officials who have been sexually satisfied. The use of such diction to reinforce the impression to the reader about the state of sexual abuse. Sociologically, the social situation of the prostitutes and the authorities or officials as it is a reflection of the social life of communities in the big city, not only in Indonesia but also in other countries.

In his poem entitled "Nyanyian Angsa", Rendra more strongly describes the dehumanization of women prostitutes. This is evident from the following verses.

Majikan rumah pelacuran berkata kepadanya:

"Sudah dua minggu kamu berbaring.

Sakitmu makin menjadi.

Kamu tak lagi hasilkan uang.

Malahan padaku kamu berhutang.

Ini biaya melulu.

Aku tak kuat lagi.

Hari ini kamu mesti pergi.",

Before the dehumanization of women contained in the above verses disclosed, it is first performed heuristically readings. Heuristically Reading looks as follows.

(seorang) Majikan rumah pelacuran berkata kepadanya (Maria Zaitun)

Sudah dua minggu (lamanya) kamu berbaring (sakit)

Sakitmu (se) makin menjadi (parah)

Kamu tak lagi (bisa meng) hasilkan uang (untukku).

Malahan padaku kamu (memiliki hutang) berhutang.

(hal) Ini (menghabiskan) biaya (saja) melulu.

Aku tak kuat lagi (merawatmu).

Hari ini (juga) kamu mesti pergi (dari sini)

The Dehumanization of women prostitutes in hermeneutics in the verses above show that female prostitutes are treated inhumanely by the pimps. Maria Zaitun as a prostitutes in sickness / sudah dua minggu kamu berbaring /, even the pain got worse, she expelled because she cannot earn money anymore. Therefore, Maria Zaitun was a bit old and ailing, would no longer be able to serve her men customer, even she had a debt to the pimps/ malahan padaku kamu berhutang/. Maria Zaitun's employers can no longer afford the treatment so that her pimps said: / aku tak kuat lagi/ /hari ini kamu mesti pergi /. With proper diction and firm, such as: "hasilkan", "malahan", "melulu" and "mesti" indicates the firmness of her employer as well as strengthening the impression of the inhumane treatment received by Maria Zaitun. 
Circumstances experienced by Maria Zaitun, sociologically illustrates the arbitrariness of the pimps which led to the emergence of new social problems. This indicates the occurrence of dehumanization against Maria Zaitun as female prostitutes.

The Dehumanization experienced by Maria Zaitun when she went to the doctor to treat her severe syphilis. Maria Zaitun examined by a doctor and asked to undress that have been attached to the sore in his armpit. This situation is illustrated by the following Rendra's poetry.

"Cukup," kata dokter.

Dan ia tak jadi mriksa.

Lalu ia berbisik kepada jururawat

"Kasih ia injeksi vitamin C."

Dengan kaget jururawat berbisik kembali:

"Vitamin C?

Dokter, paling tidak ia perlu Salvarsan.'

"Untuk apa?

Ia tak bisa bayar.

Dan lagi sudah jelas ia hampir mati.

Kenapa mesti dikasih obat mahal

yang diimport dari luar negeri?"”

If the reading is done heuristically, then the verses above looks as follows.

Cukup (Maria Zaitun) kata dokter.

Dan ia (dokter) tak jadi mriksa.

Lalu ia (dokter) berbisik kepada jururawat

(tolong) Kasih ia injeksi vitamin C.

Dengan kaget jururawat berbisik kembali (kepada dokter):

Vitamin C (dokter)?

Dokter, paling tidak ia perlu (obat) Salvarsan."

Untuk apa (diberi Salvarsan)?

Ia tak bisa bayar (lagi)

Dan lagi (pula) sudah jelas ia hampir mati.

Kenapa mesti dikasih obat (yang) mahal

yang diimport dari luar negeri?

In hermeneutics, dehumanization against Maria Zaitun who was ailing syphilis is done by a doctor. The doctor is supposed to help everyone who is sick without asking whether she has the money to pay or not. Although Maria Zaitun doesn't have money, but doctors are still willing to accept Maria Zaitun, but did not review it because it is considered that the disease is severe and / Ia tak bisa bayar // dan lagi sudah jelas ia hampir mati /. The use of word "mati" reinforces the dehumanization experienced by Maria Zaitun because the word "mati" just addressed to animals. It's mean that Maria Zaitun equated with animals. Maria Zaitun disease severity is expressed in terms of diction "borok" are intended to reinforce the impression of the severity of Maria Zaitun's disease. Therefore, the doctors simply ordered the nurse to give Maria Zaitun vitamin C, even though he should have got Salvarsan imported from abroad / "Kasih ia injeksi vitamin C." // Dokter, paling tidak ia perlu Salvarsan. "/. It means, the doctor has indirectly insulted Maria Zaitun.

Sociologically, dehumanization against Maria Zaitun shows that their indifference rich society (doctors) to poor people (Maria Zaitun). Social condition of society as it often happens in developing countries, including Indonesia. Money or material are tool to measure a person gets social services or not, even the poor become poverty victims.

In another poem, entitled "Pesan Pencopet Kepada Pacarnya", dehumanization of women experienced by Sitti, the girlfriend of a pickpocket. Dehumanization against Sitti revealed by Rendra as shown in the following verses.

Sitti,

kini aku makin ngerti keadaanmu.

Tak 'kan lagi aku membujukmu

untuk nikah padaku

dan lari dari lelaki yang miaramu.

Heuristically readings the poem above would looks as follows.

Sitti (pacarku)

kini aku makin ngerti keadaanmu (sekarang)

(tidak)Tak 'kan lagi aku membujukmu 
untuk (mau) (me)nikah (ke)padaku

dan lari dari lelaki yang miaramu (itu)

Dehumanization experienced by Sitti is caused by unofficially married by a man, but only as a pets. Rendra uses the word "miaramu" to reveal the dehumanization because the word "Miara" just for the animals. The word "Miara" comes from the word "memelihara" that have been assimilated and abbreviated. It's meaning that Sitti regarded as free animals who are treated by the preserve. Apparently, Sitti would be allowed because the circumstances force her / kini aku ngerti keadaanmu / either because of poverty or because it is helpless against the man who hold it. Sociologically, the poor and the weak will be powerless when faced with economic or physical strength.

Dehumanization against Sitti, is also done by her boyfriend because she got pregnant without marrying. Rendra depict this through the following poem.

Nasibmu sudah lumayan.

Dari babu jadi selir kepala jawatan.

Apa lagi?

Nikah padaku merusak keberuntungan.

Masa depanku terang repot.

Sebagai copet nasibku untung-untungan.

Ini bukan ngesah.

Tapi aku memang bukan bapak yang baik

untuk bayi yang lagi kaukandung.

Through heuristically reading, the verses above would appear as follows.

Nasibmu sudah lumayan (sekarang)

(mulai) Dari babu (hingga) (men)jadi selir kepala jawatan.

Apa lagi?

Nikah padaku (hanya) merusak keberuntungan(mu)

Masa depanku terang (sangat) repot.

Sebagai (seorang) copet nasibku (pasti) untung-untungan.

Ini bukan ngesah.

Tapi aku memang bukan bapak yang baik

untuk bayi (kita) yang lagi kaukandung.

In hermeneutics, the verses above show that Sitti's boyfriend has done dehumanization against hem since before she became a concubine or pet of the department head, she was already pregnant because it was impregnated by her boyfriend. However, her boyfriend did not marry her because he was a pickpocket who could not provide the adequately for Sitti / nikah padaku merusak keberuntungan // Masa depanku terang repot. // Sebagai copet nasibku untung-untungan. / Rendra uses the word "repot" and "untung-untungan" to describe the hardship and obscurity of life when married to a pickpocket. Therefore, the pickpocket realized that /.... aku memang bukan bapak yang baik//untuk bayi yang lagi kaukandung/. Rendra also use the word "babu" and "selir" to reinforce the dehumanization experienced by Sitti / Dari babu jadi selir kepala jawatan 1. The word "babu" to describe people who are helpless and can be treated arbitrarily by the employer. The word "selir" means a wife who are considered as pets. The function of the diction is to reinforce the dehumanization experienced by Sitti.

Sociologically, shows that the dehumanization of women can be done by everyone, either by the person who is economically or not. The dehumanization of women because the women are weak creatures, especially when dealing with men. The powerlessness of women is even greater if they live in poverty. That is, the dehumanization of women occurred because of the powerlessness of women, both in the field of socioeconomic and physical. The meaning behind the dehumanization of women is a society should treat women prostitutes as human beings with dignity and status.

\section{Conclusion}

From the analysis of the three Rendra's poems, "Bersatulah Pelacur-pelacur Kota Jakata", "Nyanyioan Angsa" and "Pesan Pencopet Kepada Pacarnya" seemed occurs dehumanization of women, especially women prostitutes. The dehumanization is the result of the powerlessness of women, both socially and economically and physically. Dehumanization by officials or people who have a lot of money. Rendra use proper dictions to describe dehumanization experienced by female prostitutes.

In semiotics, the meaning behind the dehumanization of women prostitutes is a community should be able to appreciate women as human beings, although she is a prostitute. Sociologically, the dehumanization of women, especially women prostitutes common in developing countries, like Indonesia because many 
women with low education and live in poverty, as well as women as physically being weak. The three Rendra's analyzed poetry reflects the state of developing society. Rendra revealed the dehumanization of women through the three poems because sociologically Rendra respect and love women. Dehumanization of women becomes a historical document for the life of women in developing countries, such as Indonesia.

\section{Acknowledgement}

The authors express gratitude to God Almighty for completing this study even if through a long process. On this occasion, author says thank to the various parties that have been petrified of this research process. Special thanks goes to Prof. Dr. I Nyoman Kutha Ratna, SU and Prof. Dr. Prof. Dr. I Nyoman Darma Putra M.Litt. Who have provided feedback and suggestions so that the research can be completed, although there is weakness? I hope that this research beneficial to the development of literature, especially literary criticism in Indonesia.

\section{References}

[1] Baldick, Chris. 1990. The Concise Oxford Dictionary of Literary Term. Oxford New York: Oxford University Press.

[2] Endraswara, Suwardi. 2008. Metodologi Penelitian Sastra, Epistemologi, Model, Teori, dan Aplikasi. Yogyakarta: MedPress.

[3] Jauss, HR. 1974. "Literary History as a Challenge" in Ralph Cohen (ed.) New Direction in Literary History. London: Roudledge \& Kegan Paul.

[4] Junus, Umar. 1986. Sosiologi Sastra: Persoalan Teori dan Metode. Kuala Lumpur: Dewan Bahasa dan Pustaka Kementerian Pendidikan Malaysia.

[5] Laurenso, Diana and Alan Swingewood. 1972. The Sociology of Literature. London: Paladin.

[6] North, Winfried. 1990. Handbook of Semiotics. Bloomington: Indiana University Press.

[7] Rendra, W.S. 1971. Blues Untuk Bonnie. Jakarta: Pustaka Jaya.

[8] Rendra, W.S. 1999. Memberi Makna pada Hidup yang Fana. Editor: Edy Haryono. Jakarta: Pabelan.

[9] Rendra, W.S. 2001. Penyair \& Kritik Sosial. Yogyakarta: Kepel Press.

[10] Riffatere. M. 1978. Semiotics of Poery. London: Indiana University Press.

[11] Segers. RT, 1978. The Evaluation of Literary Text. Lisse: The Peter de Ridder Press.

[12] Soekarnoputri, Rachmawati. 1996. "Peranan Wanita dalam Kehidupan Politik di Indonesia". In Perempuan Indonesia Pemimpin Masa Depan. Editor: Mely G. Tan. Jakarta: Pustaka Sinar Harapan.

[13] Sudewa, I Ketut. 2012. "Kritik Sosial dalam Puisi dan Drama W.S Rendra 1970-an-1990-an." Disertasi. Program Pascasarjana Universitas Udayana.

[14] Teeuw, A. 1980. Tergantung pada Kata. Jakarta: Pustaka Jaya.

[15] Teeuw, A. 1983. Membaca dan Menilai Sastra. Jakarta: Gramedia.

[16] Teeuw, A. 1984. Sastra dan Ilmu Sastra. Jakarta: Pustaka Jaya.

[17] Zaimar, Okke KS. 2008. Semiotik dan Penerapannya dalam Karya Sastra. Jakarta: Pusat Bahasa Departemen Pendidikan Nasional. 


\section{Biography of Authors}

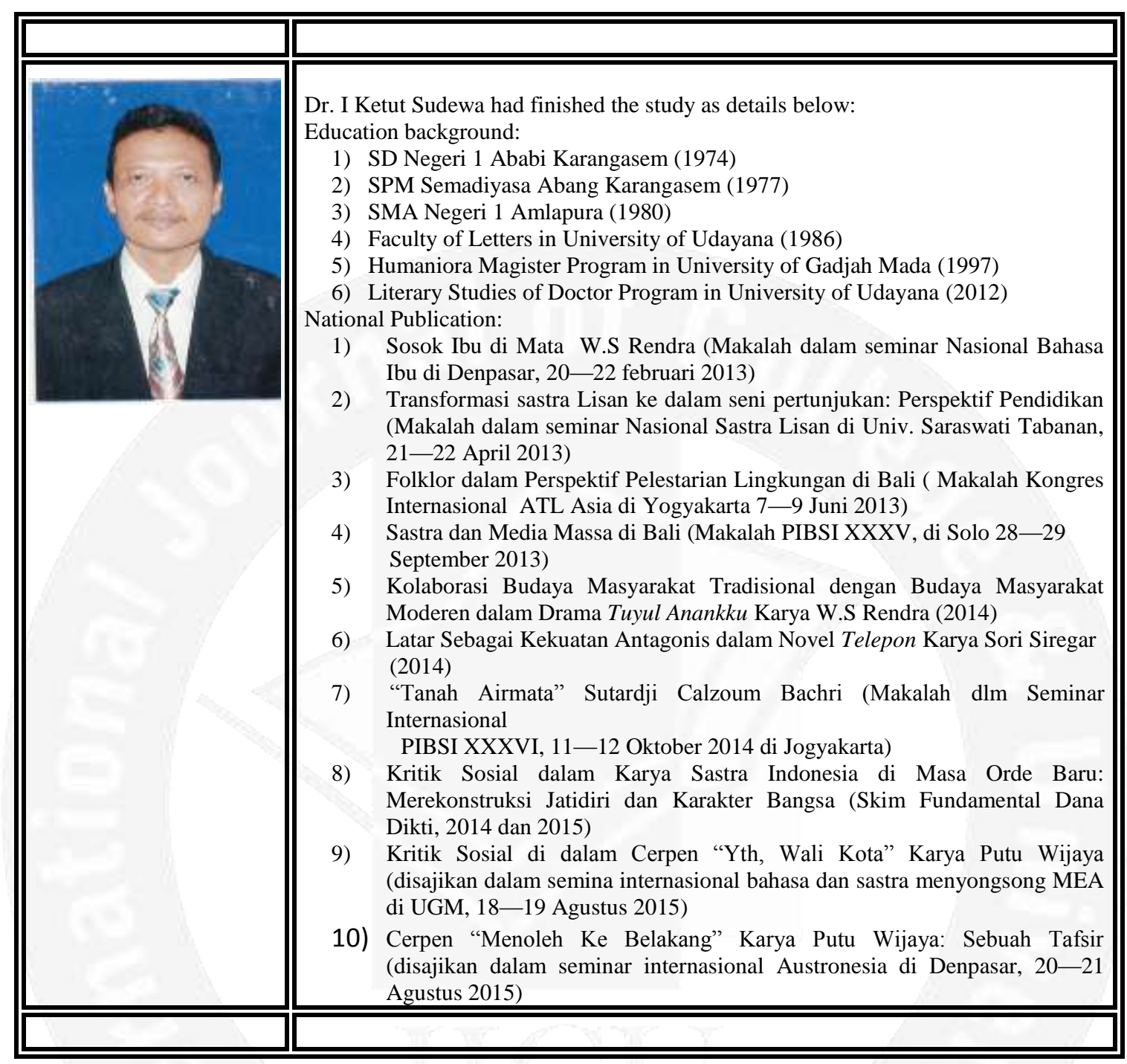

